\title{
Manajemen Pembelajaran Jarak Jauh pada Mata Pelajaran PAI dan BP SMP di Kota Tegal
}

\author{
Indah Kurniawati \\ IAIN Purwokerto, Purwokerto, Indonesia \\ Inkakurniawati80@gmail.com \\ Abdul Wachid B.S \\ IAIN Purwokerto, Purwokerto, Indonesia \\ abdulwachidbs@gmail.com
}

\begin{abstract}
Research on Distance Learning Management (PJJ) in the subject of Islamic Religious Education and Characteristics aims to identify distance learning management conducted on Islamic Education and BP SMP teachers in Tegal City. The distance learning management studied includes the Learning Management System (LMS) and PJJ Applications, the approaches and methods used, as well as the implications for competency attainment and the problems encountered. The Learning Management System and applications used are Google Classroom, WhatsApp, Google Form, Google Meeting, Zoom Cloud Meeting, and AGPAII Digital. The approach used is a scientific approach with the method of Problem Based Learning, Project Based Learning, Inquiry, and Discovery Learning. The implication of distance learning that is carried out is related to the achievement of students' competencies, including Attitude, Spiritual, Social, Knowledge and Skill Competencies. The training was carried out to overcome the problems faced, namely training on the use of LMS and PJJ applications, training on distance learning methods, and training on making ICT-based teaching materials. Effective communication with parents is needed in order to achieve competency attainment.
\end{abstract}

Keywords: PJJ; LMS; Methods; Competence 


\begin{abstract}
Abstrak
Penelitian Manajemen Pembelajaran Jarak Jauh (PJJ) pada mata pelajaran Pendidikan Agama Islam dan Budi Pekerti ini bertujuan untuk mengidentifikasi manajemen pembelajaran jarak jauh yang dilakukan pada guru PAI dan BP SMP di Kota Tegal. Manajeman pembelajaran jarak jauh yang diteliti meliputi Learning Management Sytem (LMS) dan Aplikasi PJJ, pendekatan dan metode yang digunakan, serta implikasi terhadap ketercapaian kompetensi dan permasalahan yang ditemui. Learning Management Sytem dan aplikasi yang digunakan adalah Google Classroom, WhatsApp, Google Form, Google Meeting, Zoom Cloud Meeting, dan AGPAII Digital. Pendekatan yang digunakan adalah pendekatan saintifik dengan metode Problem Based Learning, Project Based Learning, Inquiry, dan Discovery Learning. Implikasi dari pembelajaran jarak jauh yang dilakukan berhubungan dengan ketercapaian kompetensi peserta didik, meliputi Kompetensi Sikap, yakni Spiritual dan Sosial, Pengetahuan, dan Ketrampilan. Pelatihan dilakukan untuk mengatasi permasalahan yang dihadapi, yaitu Pelatihan penggunaan LMS dan Aplikasi PJJ, Pelatihan metode pembelajaran jarak jauh, dan pelatihan pembuatan bahan ajar berbasis TIK. Komunikasi efektif dengan orang tua diperlukan guna mencapai ketercapaian kompetensi.
\end{abstract}

Kata kunci: PJJ; LMS; Metode; Kompetensi

\title{
A. Pendahuluan
}

Manajemen merupakan proses untuk mencapai tujuan organisasi oleh seseorang atau sekelompok orang melalui penggunaan berbagai fungsi yakni perencanaan, pengorganisasian, kepemimpinan, serta pengendalian. Pembelajaran merupakan kegiatan dimana terjadi interaksi antar peserta didik, peserta didik dengan lingkungan belajarnya dengan tujuan perubahan tingkah laku konstruktif yang dimiliki peserta didik. Berdasarkan hal tersebut maka manajemen pembelajaran diartikan sebagai aktivitas kegiatan belajar dan mengajar melalui penerapan prinsip pembelajaran dengan langkah-langkah pembelajaran meliputi perencanaan, pelaksanaan, serta evaluasi agar rencana serta tujuan yang ditetapkan dapat tercapai (Muhlasin, 2019). Dalam Pendidikan Agama Islam (PAI) dan Budi Pekerti (BP) Manajemen pembelajaran ialah proses integrasi kegiatan belajar mengajar oleh guru yang dimulai perencanaan kegiatan belajar mengajar, evaluasi, serta tindak lanjut melalui kegiatan mendidik guna tercapainya tujuan yang terdapat dalam nilai agama Islam (Nurseha, 2018)

Pembelajaran jarak jauh adalah alternatif yang terpaksa dilakukan dalam masa pandemi Covid-19 yang dimulai di bulan Maret 2020. Pembelajaran jarak jauh atau disebut dengan pembelajaran dalam lingkaran(daring), on-line, dan e-learning. Gross, 
Muskarella, dan Pirkl mendefinisikan pembelajaran jarak jauh adalah suatu pembelajaran yang melakukan perluasan ataupun pemberian instruksi tidak dalam ruang kelas tetapi melalui lokasi lain dengan teknologi komputer, audio, video, alat komunikasi, multimedia, maupun kombinsai dari berbagai teknologi (Sanjaya (Editor), 2020) Pembelajaran daring adalah suatu kegiatan pembelajaran tanpa bertatap muka secara langsung, namun digantikan dengan pemakaian platform untuk membantu dalam proses kegiatan pembelajaran walaupun dari jarak yang jauh. Tujuan pembelajaran daring yaitu untuk memperbaiki mutu kegiatan dan layanan melalui jaringan internet dan terbuka untuk mencapai minat serta ruang-ruang belajar. (Handarini \& Wulandari, 2020) Pendidikan jarak jauh sendiri sebenarnya telah dikenal selama bertahun-tahun lalu, dimana pengertian dan batasan mengenai pendidikan jarak jauh ini terus meberkembang dari waktu ke waktu. Hal ini membuat para ahli terus mengadakan penelitian dan analisis yang ahirnya menyimpulkan batasan atau karakteristik tertentu. Keegan mengatakan batasan atau karakteristik pendidikan jarak jauh menjadi tiga pokok (Syukur, 2005). Pertama, peserta didik dan guru beraktivitas terpisah dalam kegiatan belajar. Kedua, Pelajaran disampaikan kepada siswa melalui media. Ketiga, komunikasi yang terjadi diusahakan terjadi melalui dua arah, peserta didik dan guru, peserta didik dan lembaga penyelengara, serta antara sesama peserta didik.

Pendidikan Agama Islam dan Budi Pekerti dalam satuan lembaga pendidikan di Indonesia dimana mayoritas beragama Islam mempunyai posisi yang kuat sebagaimana disebutkan pada UU No. 20 Tahun 2003 tentang Sisdiknas Bab V Pasal 12 ayat 1 point (a) bahwa setiap peserta didik mempunyai hak untuk memperoleh pendidikan agama yang sama dengan agama/keyakinan yang dianutnya dan pengajarannya diberikan oleh guru yang memeluk agama yang sama. Tujuan dari Pendidikan Agama Islam dan Budi Pekerti di sekolah umum adalah terbentuknya kepribadian peserta didik yang berlandaskan iman dan taqwa pada Allah SWT, tertanamnya akhlak mulia yang termanifestasikan melalui sikap serta perilaku dalam keseharian dan menjadi warna pada proses terbentuknya watak bangsa. Diantara indikator terbentuknya kepribadian yang dilandasi keimanan dan ketaqwaaan tercermin dalam penerapan Rukun Iman dan Rukun Islam dalam hidup. Keimanan dalam bentuk ketauhidan adalah manifestasi keyakinan kepada Allah Swt, Malaikat, Kitab, Nabi, Hari Kiamat dan Takdir. Ketaqwaan adalah bukti keimananan yang termanifestasi dalam kemauan menjalankan perintah Allah Swt sebagai pokok ibadah bagi seorang muslim. Yakni, mengucapkan dua kalimat syahadat, mendirikan sholat, membayar zakat, menunaikan puasa, dan menunaikan Haji. Selain Rukun Islam dan Rukun Iman, Ihsan adalah bagian yang tidak terpisahkan bagi seorang muslim. Ihsan termanifestasi dalam perilaku yang ditunjukkan dengan akhlaqul karimah.. 
Penyelenggaraan Pendidikan Agama Islam dan Budi Pekerti pada sekolah harus mengintegrasikan berbagai aspek pengajaran, yakni pengamalan serta pengalaman peserta didik. Hal ini berarti kegiatan dalam proses belajar mengajar dalam kelas wajib diimbangi dengan kegiatan pembiasaan melaksanakan ibadah di sekolah, mempunyai keterkaitan dan hubungan baik dengan lingkungan sekitar sekolah, serta penerapan nilai dan norma akhlak terpuji. Problematika Pendidikan Agama Islam dan Budi Pekerti sekarang ini adalah pelaksanaan pembelajaran karena diakibatkan pandemi Covid-19. Proses pembelajaran pada Pendidikan Agama Islam dan Budi Pekerti di masa pandemi Covid-19 ini seakan mengalami lompatan ke belakang. Problematika ini dapat dilihat dari sisi kesiapan lembaga pendidikan dalam sarana dan prasarana, serta guru dan peserta didik dalam proses kegiatan pembelajaran. Proses belajar dan mengajar tidak bisa dilaksanakan secara optimal, terutama dalam hal penguasaan kompetensi ketrampilan dan pembiasan beribadah serta akhlaqul karimah.

Berkaitan dengan pandemi virus Covid-19 Kemendikbud RI mengambil kebijakan dengan dikeluarkannya surat edaran bernomor 4 tahun 2020 mengenai Pelaksanaan Kebijakan Pendidikan dalam Masa Darurat Penyebaran Corona Virus Disease (Covid-19) dan SE nomor 15 tahun 2020 mengenai Pedoman Penyelenggaran Belajar dari Rumah dalam Masa Darurat Penyebaran Corona Virus Disease (Covid-19). Pembelajaran jarak jauh adalah langkah yang paling logis untuk dipilih. Dinamika dan Problematika terjadi mewarnai pendidikan jarak jauh yang dilakukan, demikian juga pada Pendidikan Agama Islam dan Budi Pekerti. Ketidaksiapan menghadapi kondisi di luar prediksi ini membuat praktisi pendidikan harus memikirkan solusi yang tepat agar pendidikan tetap berlangsung meskipun dalam keterbatasan, terutama keterbatasan dalam kegiatan pembelajaran jarak jauh.

Berdasarkan alasan-alasan tersebut penelitian ini dilaksanakan. Penelitian manajemen pembelajaran jarak jauh PAI dan BP ini dilakukan di Kota Tegal dan ditujukan pada guru Pendidikan Agama Islam dan Budi Pekerti SMP. Penelitian ini adalah penelitian kualitatif deskriptif. Sedangkan teknik pengumpulan data menggunakan observasi, angket, wawancara, dan studi dokumen. Data yang telah terkumpul dianalisis dengan menelaah seluruh data-data yang diperoleh, disusun dibandingkan untuk ditarik kesimpulan demi memperoleh jawaban dari permasalahan.

Artikel yang berjudul Manajemen pembelajaran Dalam meningkatkan efektivitas proses belajar mengajar di masa pademi Covid-19 (Saifulloh \& Darwis, 2020), menyebutkan bahwa manajemen pembelajaran mempunyai kedudukan sangat penting untuk meningkatkan efektifitas proses pembelajaran apa lagi di masa darurat penyebaran virus Covid-19. Artikel tersebut menyoroti kesulitan-kesulitan dalam kegiatan proses pembelajaran dari berbagai faktor, yakni sarana dan prasarana serta 
peserta didik dan keluarga peserta didik. Peran guru dalam memanage atau pengelola pembelajaran sangat dibutuhkan dalam mengefektivitaskan proses kegiatan pembelajaran di masa pandemi covid 19, dalam pembelajaran yang dilakukan dengan daring maupun luing.

Artikel penelitian yang berjudul Manajemen Pembelajaran Luring dan Daring dalam Pencapaian Kompetensi (Solong, 2021) menganalisa tentang manajemen dalam kegiatan pembelajaran secara luring maupun daring terhadap ketercapaian kompetensi dasar. Hasil dari penelitian ini terdapat perbedaan manajemen diantara pembelajaran yang dilakukan dengan luring atau daring baik dari metode, media, ataupun proses kegiatan pembelajaran. Kedua manajemen pembelajaran (luring maupun daring) dilakukan dengan terintegrasi dan aling mendukung ketercapaian kompetensi dasar karena baik pembalajaran luring maupun daring masing-masing sepenuhnya belum tercapai maksimal.

Penelitian dengan judul Pelaksanaan Pembelajaran Jarak Jauh PAI SD di Kecamatan Kutawaringin merupakan artikel penelitian yang bertujuan mengetahui pelaksanaan PJJ SD di kecamatan kutawaringin (Fauzi, 2020). Dampak ari tersebar luasnya virus covid 19 adalah pelaksanaan kegiatan pembelajaran PAI terbagi menjadi tiga pola besar, yakni daring penuh, luring penuh, dan kombinasi. Problematika yang ditemui oleh guru diidentifikasi berasal dari peserta didik, faktor internal guru, yakni kompetensi guru itu sendiri, dan faktor eksternal

Penelitan-penelitian tentang manajemen pembelajaran termasuk pembelajaran jarak jauh tersebut dilakukan pada tingkat SD dan MI. Karakteristik peserta didik, kompetensi dasar, dan manajeman yang dilakukan tentu sangat berbeda dengan peserta didik pada tingkat SMP dimana penelitian ini dilakukan. Selain itu pada penelitian terdahulu tidak fokus hanya kepada pembelajaran dengan cara luring tetapi juga pembelajaran daring. Saifulloh dan Darwis menekankan pada permasalahan yang ditemui dan peran guru dalam meningkatkan efektifitas. Sedangkan pada penelitian ini tidak terfokus pada hal tersebut.

Penelitian manajemen pembelajaran jarak jauh PAI dan BP SMP di Kota Tegal ini dibatasi pada LMS dan aplikasi PJJ, pendekatan dan metode yang digunakan, implikasi terhadap ketercapaian kompetensi, dan problematika yang dialami oleh GPAI dan BP. Dengan demikian, penelitian ini bertujuan untuk mengetahui kegiatan manajemen pembelajaran yang dilaksanakan oleh guru PAI dan BP SMP di Kota Tegal. Penulisan artikel ini dirasakan penulis perlu dilakukan sebagai identifikasi terhadap pelaksanaan manajeman pembelajaran jarak jauh PAI dan BP di lapangan, khususnya pembelajaran yang dilakukan dengan jarak jauh pada masa pandemi virus Covid-19. 
Melalui identifikasi permasalahan maka akan diketahui secara jelas dan terstuktur permasalahan yang dialami baik oleh guru, siswa, maupun lembaga pendidikan dalam pembelajaran PAI dan BP. Hasil akhinya adalah solusi permasalahan sebagai usaha perbaikan pembelajaran PAI dan BP dapat dilakukan dengan tepat sasaran.

\section{B. Pembahasan}

\section{LMS dan Aplikasi Pembelajaran Jarak Jauh PAI dan BP}

Upaya yang dapat dilakukan oleh lembaga pendidikan sebagai langkah awal dalam pembelajaran jarak jauh adalah mengadopsi lingkungan belajar menggunakan Learning Management System (Wardhana et al., 2020). Dalam sebuah LMS terdapat fitur-fitur yang dapat memenuhi kebutuhan pengguna dalam hal pembelajaran seperti penyampaian materi, penilaian, forum diskusi online dan feedback terhadap hasil yang diserahkan.

LMS yang digunakan secara umum adalah Google Classroom. LMS ini dipilih karena sudah familiar dan cenderung mudah digunakan karena didukung fitur yang dapat dielaborasi guna mendukung proses pembelajaran. LMS dan aplikasi dalam pembelajaran jarak jauh PAI dan BP yang dilakukan oleh responden beragam, diantaranya adalah Google Classroom, Google Meet, Zoom Cloud Meeting, Google Form, Whatsapp, dan AGPAII Digital. Seluruh responden menyatakan penggunaan LMS dan aplikasi sangat diperlukan dalam PJJ dikarenakan karena pembelajaran dilakukan tidak secara langsung atau tatap muka tetapi online. LMS dan aplikasi yang digunakan tidak hanya untuk memberikan kemudahan dalam kegiatan belajar mengajar, tetapi juga bermanfaat untuk melakukan penjelasan secara virtual, memberikan bahan ajar dengan berbagai format, pemberian tugas dengan berbagai alternatif pilihan, dapat menganalisis perkembangan belajar siswa dan juga bisa menjalankan kegiatan diskusi dengan siswa.

Google Meet dan Zoom Cloud Meeting adalah aplikasi yang digunakan oleh responden untuk melakukan pembelajaran PAI dan BP secara virtual. Penggunaan virtual learning digunakan sebagai solusi permasalahan terpisahnya ruang dan waktu antara peserta didik dan guru PAI dan BP melalui media atau aplikasi. Paulina Pannen menyatakan bahwa virtual learning adalah pada proses kegiatan pembelajaran dalam kelas maya pada jaringan internet (Irawan et al., 2020). Dengan demikian pembelajaran secara virtual adalah suatu kegiatan interaktif antara peserta didik dengan aneka sumber belajar yang dilakukan secara maya dengan menggunakan teknologi jaringan internet agar bisa saling terhubung antara satu dan lain secara global tanpa mengenal batas teritorial ruang dan waktu. 
Google Form merupakan aplikasi yang banyak digunakan oleh responden dalam proses penilaian peserta didik. Google Formulir menurut Wikipedia yaitu aplikasi yang bisa digunakan dalam kegiatan administrasi dan survei yang berada dalam Google Drive bersama dengan aplikasi google yang lain, seperti google Dokumen, Google Sheets, dan Google Slides (Google Formulir, n.d.). Formulir yang menampilkan semua fitur berbagi yang dapat ditemukan dalam Dokumen, Spreadsheet, dan Slide. Google Formulir sangat membantu dalam kefektifan penilaian yang dilaksankan oleh guru PAI dan BP dikarenakan memberikan kemudahan dalam pembuatan soal dan evaluasi serta analisis hasil belajar. Peserta didik juga merasakan kemudahan dalam menjawab soal, dengan hanya mengisi link yang dibagikan peserta didik sudah dapat melaksanakan evaluasi dan mengetahui hasil evaluasi yang telah dilaksankannya. Semua responden menyatakan menggunakan google Form dan terbantu dengan aplikasi ini.

Aplikasi Whatsapp memberikan kemudahan dan keleluasan komunikasi dalam grup atau kelas pembelajaran PAI dan BP. Aplikasi WhatsApp mempunyai fitur yang lengkap, cepat, mudah mengoperasikan, serta praktis, karena hanya menggunakan telepon selular (Utomo \& Ubaidillah, 2018). Whatsapp merupakan aplikasi pesan gratis yang dapat digunakan untuk ponsel jenis android maupun ponsel cerdas lain yang memanfatkan koneksi internet yang memungkinkan guru bisa mengirim pesan, menelephon, mengirim gambar, suara, ataupun video pembelajaran kepada peserta didik. Whatsaapp atau WA sudah sangat populer dan memberikan kemudahan meskipun fitur untuk virtual atau melakukan video teleconfrence masih terbatas. Guru PAI dan BP menggunakan WA untuk lebih mempercepat komunikasi dan mendapatkan feedback dari pembelajaran jarak jauh ketika pembelajaran virtual dan pembelajaran melalui Google Classroom tidak bisa dilaksanakan secara maksimal.

AGPAII Digital adalah sebuah aplikasi yang diluncurkan oleh Asosiasi Guru Pendidikan Agama Islam Indonesia yang diluncurkan sejak Januari 2020. Aplikasi ini dirancang untuk menjadi solusi bagi permasalahan GPAI di era industri 4.0, yakni tuntutan untuk dapat mengimbangi dan memanfaatkan perkembangan teknologi yang sangat pesat. Fitur-fitur dalam AGPAII Digital membantu guru dalam menyiapkan perangkat pembelajaran dan media pembelajaran PAI dan BP. Guru juga dapat mengunduh berbagai media pembelajaran yang merupakan hasil karya guru PAI dan BP se Indonesia.

\section{Pendekatan dan Metode Pembelajaran Jarak Jauh PAI dan BP}

Pendidikan pembelajaran jarak jauh PAI dan BP dilakukan responden melalui pendekatan saintifik dengan menggunakan metode-metode pembelajran yang beragam. Pendekatan pembelajaran ilmiah atau scientific approach merupakan mekanisme untuk 
memperoleh pengetahuan melalui prosedur berdasarkan metode yang ilmiah (Nugroho, 2014) Pendekatan saintifik ialah pendekatan dalam proses kegiatan belajar mengajar dengan harapan mnimbulkan keaktifan peserta didik dalam mengkontruksi teori-teori, prinsip-prinsip, ataupun konsep-konsep melalui tahapan pengamatan, ketrampilan menanya, mengembangkan penalaran, cakap dalam pengumpulan informasi/melakuakan percobaan, menganalisis data, penarikan kesimpulan (asosiasi) dan mengomunikasikan hal-hal yang ditemukan (Kemendikbud, 2014). Pendekatan saintifik oleh dirjen pendidikan Islam dalam panduan pendekatan saintifik Pendidikan Agama Islam dan Budi Pekerti adalah proses yang memulai prosedurnya dari proses mengamati, menanya, mengumpulkan informasi, menalar atau mengasosiasi, dan mengomunikasikan (Kementerian Agama, 2014). Pembelajaran PAI dan BP yang memakai pendekatan saintifik akan menempatkan peserta didik dalam bimbingan untuk mengamati fakta fakta empiris yang berada di lapangan kemudian menanyakan mengumpulkan informasi mengasosiasikan mengambil kesimpulan secara logis serta mengkomunikasikannya.

Metode yang digunakan dalam pembelajaran jarak jauh adalah Project Based Learning Problem Based Learning, discovery, dan inquiry learning. Problem based learning adalah metode pembelajaran dengan pendekatan learner center. Menurut Tan (2003) menyebutkan ciri-ciri PBL adalah pembelajaran yang diawali melalui pemberian masalah dimana konteksnya sesuai dunia nyata, selanjutnya peserta didik dapat merumuskan masalah, mengidentifikasinya, serta mencari dan juga melaporkan solusi permasalahan (Amir, 2016) Tujuan utama dari metode Problem Based Learning ialah pengembangan kemampuan dalam bernalar kritis juga pengembangan kemampuan dalam memecahkan masalah sekaligus pengembangan kemampuan untuk aktif membangun potensi diri peserta didik sendiri.

Project Based Learning adalah metode yang mempunyai tujuan memfokuskan peserta didik melalui permasalahan-permasalahan kompleks yang digunakan untuk investigasi serta membawa peserta didik memahami pelajaran melalui investigasi (Mulyasa, 2013). Tujuan PBL adalah membimbing peserta didik bekerja melalui proyek-proyek kolaboratif, mengintegrasikan materi-materi dalam kurikulum dan membuka kesempatan kepada peserta didik guna mencari materi melalui beragam cara serta melakukan eksperimen. Pelaksanaan kegiatan belajar mengajar berbasis proyek memberi kesempatan peserta didik untuk berfikir kritis serta mampu mengembangkan kreativitas melalui pengembangan dan hasilnya adalah produk nyata berupa barang atau jasa.

Gulo dalam Al-Tabani menyatakan bahwa Inquiry merupakan rangkaian dalam kegiatan pembelajaran dengan mengerahkan kemampuan peserta didik guna mencari 
serta menyelidiki materi dengan sistematis, logis, kritis, juga analitis, pada akhirnya peserta didik bisa merumuskan penemuan-penemuannya (Al-Tabany, 2017). Pada pembelajaran inquiry guru tidak menyampaikan sejumlah materi yag harus dihafalkan peserta didik, namun guru merencanakan pembelajaran agar peserta didik dengan kemampuannya bisa menemukan materi yang wajib difahaminya, dengan demikian ia mendapatkan ilmu pengetahuan sera ketrampilan dengan menemukan sendiri tidak hanya sekedar hasil mengingat fakta saja.

Menurut Hosnan, discovery learning berguna sebagai pengembangan cara belajar aktif melalui penemuan dan penyelidikan sehingga hasil yang dapat diperoleh akan lebih kuat serta lebih tahan lama dalam ingatan (Kadri \& Rahmawati, 2015). Melalui kegiatan belajar dengan penemuan diharapkan peserta didik dapat belajar berpikir, menganalisis, serta mencoba memecahkan sendiri permasalahan yang dihadapi. Dalam pendapat lain discovery learning ialah proses pembelajaran dengan tidak angsung menyajikan pelajaran dalam bentuk final, namun diharapkan peserta didik sendiri yang mengorganisasikan (Kurniasih, 2014). Konsep dalam discovery learning akan ditemukanoleh peserta didik dalam data atau informasi yang didapat setelah melakukan serangkaian pengamatan dan percobaan. Pembelajaran dalam metode discovery ini dimaksudkan untuk membentuk kategori dan konsep sehingga memungkinkan generalisasi.

Metode pembelajaran yang dilakukan dengan jarak jauh ternyata menimbulkan problematika tersendiri bagi guru PAI dan BP. Hal ini disebabkan diantaranya adalah kesulitan menentukan metode yang tepat untuk digunakan. Langkah-langkah pembelajaran dalam metode pembelajaran PJJ efektif juga membutuhkan modifikasi yang menuntut pengembangan dan kreatifitas dari Guru.

Untuk mengatasi hal tersebut responden berpendapat pentingnya diadakan kegiatan pelatihan untuk meningkatkan ketrampilan dan pengetahuan demi tercapainya pembelajaran jarak jauh yang efektif. Gordon dalam (Safitri, 2013) menyatakan pelatihan adalah jenis kegiatan yang direncanakan secara sistematis untuk meningkatkan keterampilan, pengetahuan, dan kompetensi yang diperlukan agar pekerjaan dapat lebih efektif. Pelatihan yang mereka ingin untuk dilaksanakan beragam, bahkan ada yang menginginkan lebih dari satu jenis pelatihan. Pelatihan yang dibutuhkan dan sudah dilakukan adalah:

Pelatihan Penguasaan LMS dan aplikasi PJJ ini sangat penting dikarenakan proses kegiatan pembelajaran jarak jauh dilakukan melalui LMS dan berbagai aplikasi pendukung. Tingkat penguasaan penggunaan LMS dan Aplikasi PJJ guru PAI dan BP juga beragam. Bagi guru yang sudah melek teknologi, hal ini tidak menjadi permaslahan 
yang berarti. Namun, bagi guru yang kurang menguasai teknologi peltihan ini urgen mengingat mereka membutuhkan waktu untuk mempelajari sedangkan pembelajaran terus berlangsung.

Pelaksanaan pembelajaran yang dilakukan dengan jarak jauh ternyata menimbulkan kesulitan ketika memilih metode maupun model yang paling sesuai untuk digunakan. Pelatihan penggunaan metode dan model pembelajran dapat menjadi solusi dari permaslahan yang dihadapi agar guru mampu menciptakan pembelajaran jarak jauh yang efektif.

Bahan ajar dan media pada PJJ menuntut pengubahan pola. Keadaan sebelum PJJ yang berorientasi pada kertas dan buku beralih pada penggunaan Teknologi Informatika dan Komunikasi. Di sisi lain kemampuan guru memanfaatkan berbagai alat TIK untuk menghasilkan bahan ajar, media, video pembelajaran, dan kuis interaktif masih membutuhkan peningkatan. Dengan demikian pelatihan pembuatan bahan ajar berbasis TIK menjadi solusi peningkatan kompetensi guru dalam menciptakan pembelajaran yang efektif.

Dalam menggunakan metode pembelajaran yang dilakuakan terdapat perbedaan berkaitan dengan langkah-langkah dalam kegiatan pembelajaran jarak jauh yang diambil oleh responden. Sebagian tetap melaksanakan metode pembelajaran sesuai dengan sintak dalam metode pembelajaran yang dipilih. Responden juga ada yang melakukan inovasi dalam sintak metode pembelajaran jarak jauh yang digunakan, tetapi ada juga yang hanya melakukan sebagian langkah atau sintak dari metode pembelajaran yang digunakan

Untuk menentukan penggunaan metode pembelajaran yang dilakukan oleh responden adalah dengan terlebih dahulu melakukan survey keadaan peserta didik. Hal ini dilakukan unuk menentukan media pembelajaran yang dilakukan dan penggunaan sarana prasarana yang akan digunakan. Dengan mengetahui kondisi anak didiknya, guru bisa mengambil pendekatan maupun metode yang baik dan tepat. Supaya kegiatan pembelajaran bisa dilaksakan dengan baik, seharusnya guru telah mempersipakan modul atau materi dalam bentuk file, maupun power point, dan video pembelajaran. Bahan ajar yang disiapkan dapat dibuat sendiri, namun ada juga yang mengambil dari sumber lain yakni buku maupun internet. Pengambilan bahan ajar yang menarik dan bervariasi dari berbagai sumber dapat meningkatkan motivasi dan ketertarikan peserta didik mengikuti kegiatan pembelajaran. Sebagai bahan pertimbangan adalah penyederhanaan tujuan penguasaan materi sesuai dengan Keputusan Dirjen Pendidikan Islam Nomor 3451 Tahun 2020 tentang Juknis Penyelenggeraan Pembelajaran Pendidikan Agama Islam di Sekolah Pada Masa Kebiasaan Baru. 


\section{Implikasi Pembelajaraan Jarak Jauh Terhadap Ketercapaian Kompetensi PAI dan BP}

Pendidikan Penggunan metode pembelajaran jarak jauh yang digunakan berimplikasi pada ketercapaian kompetensi peserta didik. Peserta didik harus menguasai kompetensi yang termaktub dalam kompetisi inti. Kompetensi tersebut meliputi kompetensi sikap, kompetensi pengetahuan, dan kompetensi ketrampilan.

Kompetensi inti adalah standar kualitas lulusan sesudah menamatkan pendidikan pada suatu satuan pendidikan. Kompetensi inti ini menggambarkan hasil dari suatu proses pembelajaran yangdilakukan. Kompetensi inti adalah kompetensi utama yang digolongkan pada aspek sikap, aspek pengetahuan, juga aspek ketrampilan yang harus dikuasai pada setiap tingkatan baik tingkatan sekolah, tingkatan kelas, maupun mata pelajaran (Mulyasa, 2013). Kompetensi inti mengidentifikasikan mutu yang berimbang antara kemampuan dalam penguasaan pengetahuan dan kemampuan penguasaan berbagai ketrampilan yang dicapai. Untuk mempermudah pencapaian tujuan, pada kompetensi inti, terjadi pembagian pada ranah sikap. Kompetensi pada ranah sikap diperinci menjadi dua, yakni aspek spiritual dan aspek sosial. Sikap spiritual berkaitan dengan tujuan dalam pendidikan nasional untuk mendidik peserta didik menjadi insan yang beriman dan bertakwa. Sikap sosial terkait dengan tujuan pendidikan nasional dalam pembentukan peserta didik yang mempunyai akhlak mulia, demokratis, mandiri, serta bertanggung jawab. Sehingga rumusan KI menjadi KI-1 sikap spiritual, KI-2 sikap sosial KI-3 Pengetahuan KI-4 Ketrampilan.

Kompetensi sikap spiritual adalah usaha dalam membentuk anak didik menjadi insan dengan keimanan dan kertaqwaan kepada Tuhan YME melalui penghormatan, penghayatan, dan pengamalan ajaran agama yang dianut (Kurniasih, 2014) Kompetensi sikap sosial adalah sikap yang dimiliki seseorang berkaitan dengan dirinya dan orang lain atau masyarakat yang mempunyai tujuan menjaga hubungan baik dengan orang lain, agar bisa hidup berdampingan dan saling memberikan manfaat (Wiguna, 2017) Pada pencapaian kompetensi spiritual dan sosial yang biasanya dilakukan denga teknik observasi, penilaiai diri sendiri, dan penilaian teman sebaya tidak bisa maksimal dilaksankan. Terutama observasi secara langsung sikap spiritual dan sosial peserta didik. Penilaian teman sebaya pun demikian.

Kompetensi pengetahuan mencerminkan konsep-konsep keilmuan yang seharusnya dikuasai oleh peserta didik setelah melewati rangkaian kegiatan proses belajar mengajar. Terdapat 4 dimensi pengetahuan yaitu pengetahuan faktual, konseptual, prosedural, serta metakognitif yang meliputi ketrampilan dalam berpikir mulai dari tingkatan bawah atau rendah hingga tingkat tertinggi (Khotimah, 2019). 
Sebagian besar responden menyatakan metode pembelajaran yang dipilih dan dan digunakan sangat mendukung ketercapaian kompetensi pengetahuan. Pada kompetensi pengetahuan proses penilaian dapat dilaksankan dengan baik secara daring. Responden yang menyatakan kurang tercapai pada kompetensi pengetahuan dikarenakan permasalahan hanya pada tingkat partisipasi peserta didik yang tidak maksimal. Kurangnya motivasi siswa dalam PJJ menjadi problematika yang penting untuk selalu diperhatikan. Imbas dari rendahnya motivasi siswa dalam tingkat partisispasi rendah dalam mengikuti PJJ, keengganan mengerjakan tugas, dan penguasaan materi pembelajaran. Untuk meningkatkan motivasi dan partisipasi siswa maka kegiatankegiatan daring yang menarik dapat dilakukan.

Ragamnya program dari internet, kemudahan akses internet, serta berbagai fitur teknologi seperti aplikasi games online menjadi pisau bermata dua. Sangat menguntungkan, namun disisi lain menimbulkan ketertarikan peserta didik untuk menjelajahi sehingga mengalihkan dari fungsi utamanya. Dimana perhatian peserta didik terhadap PJJ berkurang karena keasyikan bereksplorasi, sehingga kuota lebih sering digunkaan untuk kegiatan browshing, games, dan bermain medsos.

Proses penilaian agar mencapai input yang maksimal harus dilakukan dengan kombinasi berbagai LMS dan aplikasi daring maupun luring dalam pengambilan dan penyerahan tugas mandiri. Flexibilitas dalam proses penilaian dan waktu pengumpulan tugas menjadi langkah yang harus digunakan demi ketercapaian kompetensi pengetahuan peserta didik. kegiatan-kegiatan daring yang menarik dilakukan untuk meningkatakan motivasi dan partisipasiswa.

Kompetensi keterampilan yang diharapkan dalam kurikulum 2013 yaitu keterampilan yang berguna untuk mengembangkan dan mengeksplorasi pengetahuan (Khotimah, 2019). Kompetensi keterampilan juga setara dengan kompetensi pengetahuan alasannya adalah supaya peserta didik tidak hanya mengetahui teori namun yang lebih penting adalah mengetahui aplikasi dan dapat merealisasikannya. Pada kompetensi ketrampilan responden menemui permasalahan, terutama pada materi penguasan ketrampilan praktek beribadah, karena guru tidak dapat secara langsung memantau. Sehingga kesulitannya adalah peserta didik tidak mendapatkan bimbingan secara maksimal. PJJ membutuhkan partisispasi orang tua yang tinggi, karena kegiatan PJJ dilakukan di rumah. Fungsi guru sebagai pembimbing dan pengawas pembelajaran beralih kepada orang tua. Hal ini tidak dapat secara maksimal dilaksanakan karena tingkat pendidikan yang beragam, faktor kesibukan, faktor sosial ekonomi, dan faktor emosional orang tua peserta didik. Pembuatan jaringan komunikasi yang efektif antara fihak sekolah, guru dengan wali maupun orang tua dari peserta didik dan kegiatan home visit bisa menjadi solusi permasalahn ini. 
Permasalahan pokok dalam PJJ adalah kepemilikan alat yang mendukung pembelajaran seperti HP, komputer atau laptop, dan ketersediaan kuota maupun signal dari operator selular. Hal ini dapat dilihat dengan masih dapat ditemukan peserta didik yang tidak mempunyai HP, penggunaan HP secara bergantian dalam keluarga, dan kualifikasi HP yang digunakan. Problem signal dan kuota merupakan hal yang paling banyak dikeluhkan oleh peserta didik. Penyediaan sarana prasarana di sekolah yang bisa diakses oleh peserta didik yang mengalami kendala dapat menjadi solusi. Dengan menerapkan protokol kesehatan peserta didik yang memiliki keterbatasan sarana dan prasarana PJJ di rumah dapat menggunakan fasilitas sekolah. Program pemberian kuota belajar dari kemendikbud membantu dalam masalah kuota serta mengurangi keluhan baik dari orangtua maupun peserta didik.

\section{Simpulan}

Pondok Manajemen Pembelajaran Jarak Jauh mata Pelajaran Pendidikan Agama Islam dan Budi Pekerti di Kota Tegal dilakukan dengan menggunakan LMS dan aplikasi beragam, diantaranya adalah Google Classroom, Google Meet, Zoom Cloud Meeting, Google Form, Whatsapp, dan AGPAII Digital.. Pembelajaran jarak jauh PAI dan BP dilakukan melalui pendekatan saintifik dengan beberapa metode, yakni Project Based Learning, Problem Based Learning, Discovery, dan Inquiry Learning. Metode pembelajaran yang dilakukan dengan jarak jauh ternyata menimbulkan problematika tersendiri bagi guru PAI dan BP Responden berpendapat untuk perlu selalu mengupgrade ketrampilan dan pengetahuan yang dimiliki demi efektivitas pembelajaran yang dilakukan dalam pembelajaran jarak jauh. Pelatihan yang dibutuhkan adalah pelatihan penggunaan LMS dan aplikasi daring, pelatihan pembuatan media/video pembelajaran, dan pelatihan metode-metode pembelajaran. Efektivitas pembelajaran dapat terjadi apabila metode pembelajaran sesuai dengan realitas di lapangan, sehingga inovasi berupa penambahan, dan penggantian langkah pembelajaran dapat dilakukan. Implikasi penggunaan metode pembelajaran terhadap kompetensi yang dicapai peserta didik mendukung ketercapaian kompetensi pengetahuan, tetapi disisi lain terutama pada kompetensi spiritual, sikap, serta ketrampilan memerlukan peran orang tua yang besar dalam ketercapaian kompetensi peserta didik. 


\section{DAFTAR PUSTAKA}

AGPAII Luncurkan Aplikasi Digital Untuk Meringankan Tugas Guru. (n.d.). Retrieved March 22, 2021, from https://jateng.kemenag.go.id/warta/berita/detail/agpaiiluncurkan-aplikasi-digital-untuk-meringankan-tugas-guru

Al-Tabany, T. I. B. (2017). Mendesain Model Pembelajaran Inovatif, Progresif dan Kontekstual. Kencana.

Amir, M. T. (2016). Inovasi Pendidikan Melalui Problem Based Learning (Cet.5). Kencana.

Fauzi, A. (2020). Pelaksanaan Pembelajaran Jarak Jauh PAI SD Di Kecamatan Kutawaringin [Other, Universitas Pendidikan Indonesia]. http://repository.upi.edu

Google Formulir. (n.d.). Retrieved March 22, 2021, from https://id.wikipedia.org/wiki/Google_Formulir

Handarini, O. I., \& Wulandari, S. S. (2020). Pembelajaran Daring Sebagai Upaya Study From Home (SFH) Selama Pandemi Covid 19. Jurnal Pendidikan Administrasi Perkantoran (JPAP), 8(3), 496-503.

Innovative Techniques in Instruction Technology, E-learning, E-assessment a... Google Books. (n.d.). Retrieved March 22, 2021, from https://www.google.co.id/books/edition/Innovative_Techniques_in_Instruction_Te $\mathrm{c} / \mathrm{ngQH} 8 \mathrm{~S} 7 \mathrm{Zx} 0 \mathrm{gC}$ ?hl=id\&gbpv=1\&dq=definition+of+learning+management+syst em\&pg $=$ PA59\&printsec $=$ frontcover

Irawan, E., Arif, S., Hakim, A. R., Fatmahanik, U., Fadly, W., Hadi, S., Pertiwi, F. N., Fauziah, H. N., Santoso, L., Pahlevi, F. S., Hidayati, N., Noviana, L., Ajhuri, K. F., \& Aini, S. (2020). Pendidikan Tinggi Di Masa Pandemi: Transformasi, Adaptasi, dan Metamorfosis Menyongsong New Normal. Zahir Publishing.

Kadri, M., \& Rahmawati, M. (2015). Pengaruh model pembelajaran discovery learning terhadap hasil belajar siswa pada materi pokok suhu dan kalor. Jurnal Ikatan Alumni Fisika Universitas Negeri Medan, 1(1), 21-24.

Kemendikbud. (2014). Pendekatan dan strategi scientific. Kemendikbud.

Kementerian Agama. (2014). Panduan Pendekatan Saintifik Kurikulum 2013 Pendidikan Agama dan Budi Pekerti.

Khotimah, K. (2019). Pengaruh Kompetensi Inti PAI (Sikap Spiritual, Sikap Sosial, Pengetahuan, Dan Ketrampilan) Terhadap Life Skill Siswa Di SMP Islam SeKecamatan Kedungwaru Kabupaten Tulung Agung Tahun Ajaran 2017/2018 [IAIN Tulungagung]. http://repo.iain-tulungagung.ac.id/13639/

Kurniasih, I. (2014). Implementasi kurikulum 2013: Konsep \& penerapan (Cetakan kedua). Kata Pena.

Muhlasin, M. (2019). Manajemen Pembelajaran dalam Rangka Meningkatkan Prestasi Belajar. Akademika, 15(1), 62-75. 
Mulyasa, E. (2013). Pengembangan dan implementasi kurikulum 2013 (Cetakan pertama). PT Remaja Rosdakarya.

Mu'ayyadah, and Noor Fatmawati. 2021. "Pemanfaatan Teknologi Sebagai Pembelajaran E-Learning Google Classroom Pada Mata Pelajaran IPS." Asanka: Journal of Social Science and Education 2(1): 31-45. https://jurnal.iainponorogo.ac.id/index.php/asanka/article/view/2364.

Nugroho, T. (2014). Pendekatan scientific, model, dan strategi pembelajaran dalam kurikulum 2013. Lingua Humaniora, 8, 797-808.

Nurseha, A. (2018). Manajemen Pembelajaran Pendidikan Agama Islam di Sekolah. AN NIDA JOURNAL, 7(1), Article 1. http://103.66.199.204/index.php/NIDA/article/view/340

Safitri, E. (2013). Pengaruh Pelatihan Dan Disiplin Kerja Terhadap Kinerja Karyawan. Jurnal Ilmu Manajemen (JIM), I(4), Article 4. https://jurnalmahasiswa.unesa.ac.id/index.php/jim/article/view/6262

Saifulloh, A. M., \& Darwis, M. (2020). Manajemen Pembelajaran dalam Meningkatkan Efektivitas Proses Belajar Mengajar di Masa Pandemi Covid-19. Bidayatuna: Jurnal Pendidikan Guru Mandrasah Ibtidaiyah, 3(2), 285-312. https://doi.org/10.36835/bidayatuna.v3i2.638

Sanjaya (Editor), R. (2020). 21 Refleksi Pembelajaran Daring di Masa Darurat. SCU Knowledge Media.

Solong, N. P. (2021). Manajemen Pembelajaran Luring dan Daring Dalam Pencapaian Kompetensi. Tadbir: Jurnal Manajemen Pendidikan Islam, 9(1), 19-32. https://doi.org/10.30603/tjmpi.v9i1.2064

Syukur, F. (2005). Inovasi Bidang Pendidikan. JUrnal Pendidikan Islami, 14(1). library.walisongo.ac.id/digilib/files/disk1/22/jptiain-gdl-jou-2005-fatahsyuku1063-06_Inova-n.pdf

Utomo, S. W., \& Ubaidillah, Moh. (2018). Pemanfaatan Aplikasi Whatsaapp Pada Pembelajaran Berbasis Masalah Untuk Mata Kuliah Akuntansi Internasional Di Universitas PGRI Madiun. Kwangsan: Jurnal Teknologi Pendidikan, 6(2), 199211. https://doi.org/10.31800/jtp.kw.v6n2.p199--211

Wardhana, A. C., Segara, A. J. T., Adhinata, F. D., \& Rakhmadani, D. P. (2020). Pelatihan Pembelajaran Jarak Jauh Menggunakan Learning Management System Berbasis Moodle Untuk Guru Di SMK Maarif NU 2 Ajibarang. LOGISTA - Jurnal Ilmiah Pengabdian Kepada Masyarakat, 4(2), 231-237. https://doi.org/10.25077/logista.4.2.231-237.2020 
Sri Rokhmiyati 